\title{
First contribution to the description of reproductive structures of Nelsonia goldmani (Rodentia: Cricetidae)
}

\author{
M. Ángel León-Tapia ${ }^{1,2^{*}}$ and Fernando A. Cervantes ${ }^{2}$ \\ ${ }^{1}$ Laboratorio de Sistemática Filogenética, Biología Evolutiva, Instituto de Ecología A. C. Carretera antigua a Coatepec 351 , CP. \\ 09170, Xalapa. Veracruz, México. Email: mal@st.ib.unam.mx (MALT). \\ ${ }^{2}$ Instituto de Biología, Departamento de Zoología, Universidad Nacional Autónoma de México. Circuito Deportivo s/n, CP. 04510, \\ Ciudad de México. Ciudad de México, México. Email: fac@ib.unam.mx (FAC). \\ *Corresponding author
}

Nelsonia is a genus of rodent endemic to Mexican highlands with only two species: N. neotomodon (Western diminutive woodrat) and $N$. goldmani (Goldman's diminutive woodrat). These species are taxonomically interesting because the few internal and external morphological differences were reported between them. Unfortunately, the scarcity of specimens and preserved internal organs available of these species limits the information to perform taxonomic studies. Hence, the objective of this study was to describe the reproductive structures in one specimen of N. goldmani collected in the biogeographic region known as Transmexican Volcanic Belt, located in the highlands of the central Mexico. We describe the external structures of the phallus and take nine measurements. The baculum was measured and described after using the classical methodology to clear, stain and preserve the whole phallus. The spermatozoa and inner testes were described using light microscopy, scanning electron microscopy, and histological techniques. Testicular volume was $319.64 \mathrm{~mm}^{3}$ and $1.34 \%$ of gonad somatic index. The phallus was relatively simple externally, laterally cylindrical, and dorsally resembling an elongated bottleneck. The baculum is an osseous structure with a cartilaginous part in its distal section. The sperm has a total mean length of $182.58 \mu \mathrm{m}$ with an asymmetric head, a slight depression in its base and a large recurved hook. The histological analysis of testes indicated active spermatogenesis. We found important differences in the features and form of the phallic and baculum between N. neotomodon and N. goldmani. In N. goldmani some phallic forms were different, and some features measurements were greater than $N$. neotomodon. The external structures and the internal position of the baculum differ between the two species. In addition, the sperm size in N. goldmani was greater than other rodents, even those of larger corporal size like some species phylogenetically close as Neotoma genus.

Nelsonia es un género de roedor endémico de las zonas altas de México con únicamente dos especies: N. neotomodon (rata enana del oeste) y N. goldmani (rata enana michoacana). Estas dos especies son taxonómicamente interesantes debido a las escasas diferencias morfológicas internas y externas reportadas. La escasez de especímenes y órganos internos preservados disponibles para estas especies provee información limitada para realizar estudios taxonómicos. Por lo tanto, el objetivo de este estudio fue describir las estructuras reproductivas de un espécimen de N. goldmani colectado en la región biogeográfica conocida como Faja Volcánica Transmexicana, ubicada en las zonas altas del centro de México. Se describieron las estructuras externas del falo y se tomaron nueve medidas. El báculo se midió y describió después de usar la metodología clásica para aclarar, teñir y preservarlo completo. Los espermatozoides y testículos se describieron usando microscopía óptica, microscopía electrónica de barrido y técnicas histológicas. El volumen testicular fue de $319.64 \mathrm{~mm}^{3}$ y un índice gonadosomático de 1.34 \%. El falo es externamente simple, cilíndrico en vista lateral y parecido a un cuello de botella alargado en vista dorsal. El báculo es una estructura ósea con su sección distal cartilaginosa. Los espermatozoides tienen una longitud total promedio de $182.58 \mu \mathrm{m}$, la cabeza asimétrica, con una ligera depresión en su base y un largo gancho recurvado. Los análisis histológicos de los testículos indicaron una espermatogénesis activa. Se encontraron diferencias importantes entre las estructuras y forma del falo y báculo de N. neotomodon y N. goldmani. En N. goldmani algunas formas del falo fueron diferentes y algunas mediciones en las estructuras fueron mayores que en $N$. neotomodon. Las estructuras externas y la posición interna del báculo difieren entre las dos especies. Asimismo, el tamaño del espermatozoide en N. goldmani fue mayor que otros roedores, incluso aquellos de mayor tamaño corporal como algunas especies cercanamente relacionadas filogenéticamente como el género Neotoma.

Key words: Baculum; histology; phallus; spermatozoa; taxonomy; testes.

C 2019 Asociación Mexicana de Mastozoología, www.mastozoologiamexicana.org

\section{Introduction}

Nelsonia is a genus of rodent endemic to Mexican highlands and taxonomically interesting because of scarce biological information about its ecology and evolution. The genus includes only two species, $N$. neotomodon (Western diminutive woodrat) and N. goldmani (Goldman's diminutive woodrat), and inhabits on rocky slopes, hillsides, and ravines in highlands of pine, oak, and mountainous cloud forests. Nelsonia neotomodon is distributed in the Western Sierra Madre (García-Mendoza and López-González 2005) and N. goldmani in fragmented areas along the Transmexi- can Volcanic Belt (León-Tapia and Cervantes 2018), located in central Mexico. The two species are considered as uncommon because of their scarce records (García-Mendoza and López-González 2005; León-Tapia and Cervantes 2018).

These species are taxonomically interesting because the few internal and external morphological differences reported between them. Externally, the dorsal pelage of $N$. neotomodon is cinnamon-buff and darker dorsally than laterally, dorsal surfaces of the hind feet are usually white, and the tail is distinctly bicolored with a white tip (Merriam 1897; Engstrom et al. 1992). Whereas in N. goldmani the dor- 
sal pelage is much darker with a distinct grayish cast and a fulvous but subdued lateral line, the hind feet are dusky dorsally, and the tail is indistinctly bicolor and lacks a white tip (Merriam 1903; Engstrom et al. 1992). Cranially, N. neotomodon have relatively narrow anterior zygoma and lack a zygomatic notch, whereas $N$. goldmani have relatively broad anterior zygoma with a well-developed zygomatic notch (Engstrom et al. 1992). Studies about these species are limited, and new information on internal characteristics is necessary to support the taxonomic identity of each species.

Unfortunately, the scarcity of specimens available and a lack of preserved internal organs, especially in N. goldmani, limit the available information. For example, the absence of phallus and testis structures limits the information about the reproductive system, which could be valuable taxonomic information. The penis or phallus is an excellent organ that has revealed useful characteristics for taxonomic differentiation in several North American species of rodents (Hooper 1958; Hooper 1959; Hooper 1960; $\underline{\text { Hooper }}$ and Musser 1964). The structures of the phallus vary greatly among groups while staying generally constant within a given species (Bradley et al. 1989; Simson et al. 1995). For Nelsonia genus, the first description of phallus and the internal bone of penis or baculum was from one specimen of $N$. neotomodon collected in Durango, Mexico ( 1959). However, there is no information if these structures are different from those of $\mathrm{N}$. goldmani.

The morphology of spermatozoa in small mammals has been useful in taxonomic and evolutionary knowledge of some taxa (Forman 1968; Afzelius 1982), as some genera and species have distinctive morphologies (Linzey and Layne 1974; Breed 1983). Unfortunately, Nelsonia genus spermatozoa morphology is still unknown; therefore, a description of the spermatozoa morphology could provide valuable biological information. A purely descriptive or taxonomic description of these structures could be a useful source of information in the evolutionary research of rodent diversification (Roldan et al. 1992; Bezerra 2005; Adebayo et al. 2011), especially in rare species with scarce biological material such as N. goldmani.

On the other hand, some reproductive features of testes, like gonadal size and seminiferous tubes in males, have been used to gain insight into reproductive activity in small mammals (Faulkes et al. 1991; Moreira et al. 1997; Cortés-Calva and Alvarez-Castañeda 1999), though such information in N. goldmani remains unknown. Hence, the main focus of this study was to describe the phallus, spermatozoa and inner testes structures in one specimen of $N$. goldmani to increase the taxonomic and basic biological information of this species.

\section{Materials and methods}

An adult specimen of N. goldmani was collected on 16 October 2010 in the central region of the Transmexican Volcanic Belt in Parque Natural Las Peñas, Estado de México, México $\left(19^{\circ} 55^{\prime} 11.2^{\prime \prime} \mathrm{N},-99^{\circ} 29^{\prime} 13.3^{\prime \prime} \mathrm{W}\right)$; and deposited in the Colección Nacional de Mamíferos (CNMA 46291) at the Universidad Nacional Autónoma de México, in Mexico City. The capture and manipulation of the specimen was according to guidelines provided by Sikes et al. (2016) and as stated by León-Tapia and Cervantes (2018).

The phallus and testes were removed and fixed it by immersion in a $3 \%$ glutaraldehyde solution. The testicular volume (TV), and gonad somatic index (GSI; including epididymis) was calculated according to Moreira et al. (1997) and Cortés-Calva and Álvarez-Castañeda (1999).

Phallus description. We used the classical methodology of Hooper (1958) and Lidicker (1968) to clear, stain, and preserve the phallus. External phallus morphology was analyzed before the cleaning, and staining procedures in order to avoid misinterpretation due to loss or distortion of fine structures and soft tissues because of the effects of potassium hydroxide (KOH). The illustration of the external phallus surface and baculum position was made by observation in a stereomicroscope SMZ445 (Nikon). Nine measurements were taken of the phallus and baculum as stated in Hooper (1958) and Bezerra (2005) with a digital caliper of $0.01 \mathrm{~mm}$ of precision. The measurements were: 1) Length of distal tract (LDT), distance from the base of the flexure to the distalmost point on the glans. 2) Length of glans (LG), distance on the ventral face of the glans from its base, where the glans joins the prepuce, to its distal limits. 3) Diameter of glans (DG), greatest diameter of the glans. 4) Distal diameter of glans (DDG), greatest diameter of distal glans including spines. 5) Total baculum length (TBL), greatest distance from the base of baculum to the terminal cartilaginous part. 6) Distal baculum length (DBL), greatest distance of baculum cartilaginous part. 7) Proximal baculum length (PBL), greatest distance of baculum osseous part. 8) Proximal baculum diameter (PBD), greatest breadth of the bottom of the osseous part. 9) Distal baculum diameter (DBD), greatest breadth of the top of the osseous baculum.

Spermatozoa description. For light microscopy, we removed one epididymis from the testes and prepared microslides as reported by Linzey and Layne (1974). The epididymis fragments were removed and fixed in $3 \%$ glutaraldehyde by immersion. Sperm was analyzed at $100 x$ magnification and six measurements were taken conforming to Linzey and Layne (1974) and Villalpando et al. (2000) as follows: 1) Total length (TL), distance from the top head to end of tail. 2) Head length (HL). 3) Head diameter (HD), greatest diameter of the head excluding hook. 4) length of midpiece (LM); Length of tailpiece (LT) and length of hook (LH), length from dorsal surface of the head to the end of hook. For scanning electron microscopy, the fixed epididymis was washed in $7 \%$ potassium chloride $(\mathrm{NaCl})$, dehydrated through a graded series of ethyl alcohol and then critical point dried with carbon dioxide $\left(\mathrm{CO}_{2}\right)$. Finally, samples were metalized with gold and examined in a Hitachi VP-SEM SU1510. 
Histological analysis of testes. The testes were processed using conventional histological analysis and stained with hematoxylin and eosin. The diameter of 20 representative seminiferous tubules was taken and the germinal cells were classified (spermatogonia, primary and secondary spermatocytes, and spermatids) according to size and position in the seminiferous tubule. All slides obtained for light microscopy analysis were performed with an inverted microscope Olympus IX81 and an Olympus U-TV0.5XC3 integrated camera. We took all measurements of spermatozoa and seminiferous tubules with Image-Pro plus software V.7.0.1.658 (Media Cybernetics, Rockville, MD, USA).

\section{Results}

The external measurement of the male of N. goldmani analyzed were: total length, $260 \mathrm{~mm}$; tail length, $140 \mathrm{~mm}$; hind foot length, $25 \mathrm{~mm}$; ear length, $24 \mathrm{~mm}$, and weight, $56 \mathrm{~g}$. The testes were presents in a scrotal position with an oval shape and pink-like color, both with a length of $10.94 \mathrm{~mm}$ and $7.47 \mathrm{~mm}$ of breadth, the testicular volume of both testes was $319.64 \mathrm{~mm}^{3}$ and $1.34 \%$ of gonad somatic index. The phallus was relatively simple externally, laterally cylindrical and dorsally its base was cylindrical reducing in diameter to the distal part of gland with a diameter two thirds of its base (Table 1), resembling an elongated bottleneck (Figure 1). The external surface was rigid with one quarter of the surface bare, while the rest of the surface was dotted with conical tubercles or spines surrounded in a circular depression (Figure 1d). Dorsally and ventrally, the spines appear from beyond the union of gland base and prepuce to three quarters of the total length (Figure 1a, b). The spines were larger at the base of the gland, approximately $0.31 \mathrm{~mm}$, and double the size of those at the distal area $(0.15 \mathrm{~mm})$. Furthermore, the spines were present on the distal surface of terminal gland orifice (Figure 1d).

Table 1. External and internal measures $(\mathrm{mm})$ of the phallus of one male adult specimen of Nelsonia goldmani (CNMA 46291). The measurements reported by Hooper (1954) for Nelsonia neotomodon are included. Abbreviations of measurements are in the text.

\begin{tabular}{lrr}
\hline \multicolumn{1}{c}{ Measurements } & Nelsonia goldmani & Nelsonia neotomodon \\
\hline LDT & 12.47 & \\
LG & 9.50 & 7.9 \\
DG & 3.39 & 2.9 \\
DDG & 2.17 & \\
TBL & 7.74 & 8.6 \\
DBL & 1.15 & 2.7 \\
PBL & 6.59 & 5.9 \\
PBD & 2.18 & \\
DBD & 0.62 & \\
\hline
\end{tabular}

Baculum was an osseous structure with a cartilaginous part in its distal section; this cartilaginous part is one-sixth the total length of the baculum, resembling a cone. The osseous structure was simple in form; its proximal portion was concave and becomes narrow toward the distal end, with a diameter of $0.62 \mathrm{~mm}$ at the beginning of the cartilaginous part (Table 1). The inner position of the baculum was
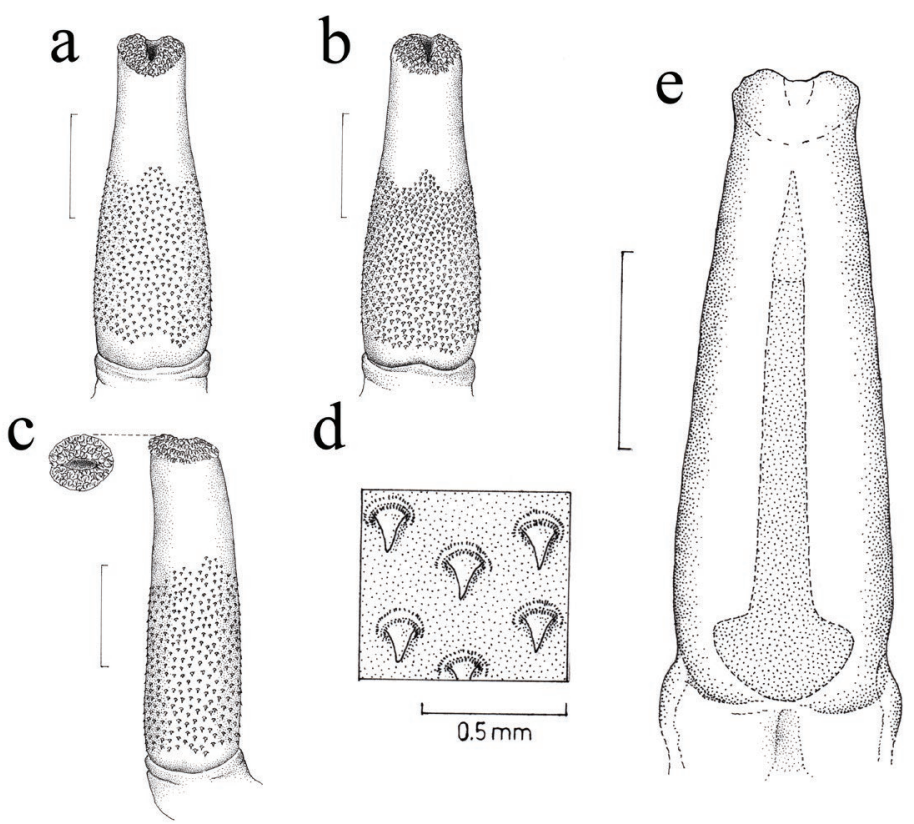

Figure 1. Phallus of one specimen of Nelsonia goldmani (CNMA 46291) showing the external and internal features. a) dorsal view, b) ventral view, c) lateral view, d) amplification of spines of the external surface of the phallus and e) dorsal view of the phallus with the internal position of baculum. Scale bar $=3 \mathrm{~mm}$.

the same as the phallus and the proximal section was at the same distance to the base of gland extending through of it to reach four fifths of the total gland length (Figure 1e).

Forty-two spermatozoa were measured and had a total mean length of $182.58 \mu \mathrm{m}$, the descriptive statistics are in Table 2. The head was asymmetric and rounded the base narrower with a slight depression in its base. The diameter was greatest at the middle of the head and it exhibits an acrosome that extends as a strong and large recurved hook (Figure 2). The base of the hook begins one third of the dorsal area from the head at an approximate $45^{\circ}$ angle. The middle piece was separated clearly from the head by a narrower section, and closer to the ventral part, the length of the middle piece was four times that of the head. Finally, tail was large, reaching three times the length of the middle piece. Histological analysis showed that compacted Leydig cells dominate the interstitial tissue with a conspicuous presence of blood vessels. Seminiferous tubules had $206.5 \mu \mathrm{m} \pm 15.2$ mean diameter, containing mature sperm in most cases (Figure 3), which indicates active spermatogenesis.

Table 2. Average, standard deviation and interval of external measures ( $\mu \mathrm{m})$ of the spermatozoa of one male adult specimen of Nelsonia goldmani (CNMA 46291). The proportion is relative to the total length of the spermatozoon. Abbreviations of measurements are in the text.

\begin{tabular}{lcrrr} 
Measurements & $\begin{array}{c}\text { Average and standard } \\
\text { deviation }\end{array}$ & Maximum & Minimum & $\begin{array}{c}\text { Relative } \\
(\%)\end{array}$ \\
\hline TL & $182.58( \pm 1.615)$ & 184.11 & 179.87 & 100 \\
HL & $11.66( \pm 0.581)$ & 12.79 & 11.02 & 6.39 \\
HD & $6.44( \pm 0.328)$ & 7.11 & 6.12 & 3.53 \\
LM & $40.07( \pm 1.320)$ & 41.79 & 38.04 & 21.95 \\
LT & $130.71( \pm 1.123)$ & 131.65 & 128.82 & 71.60 \\
LH & $15.22( \pm 0.348)$ & 15.88 & 14.70 & 8.34 \\
\hline
\end{tabular}




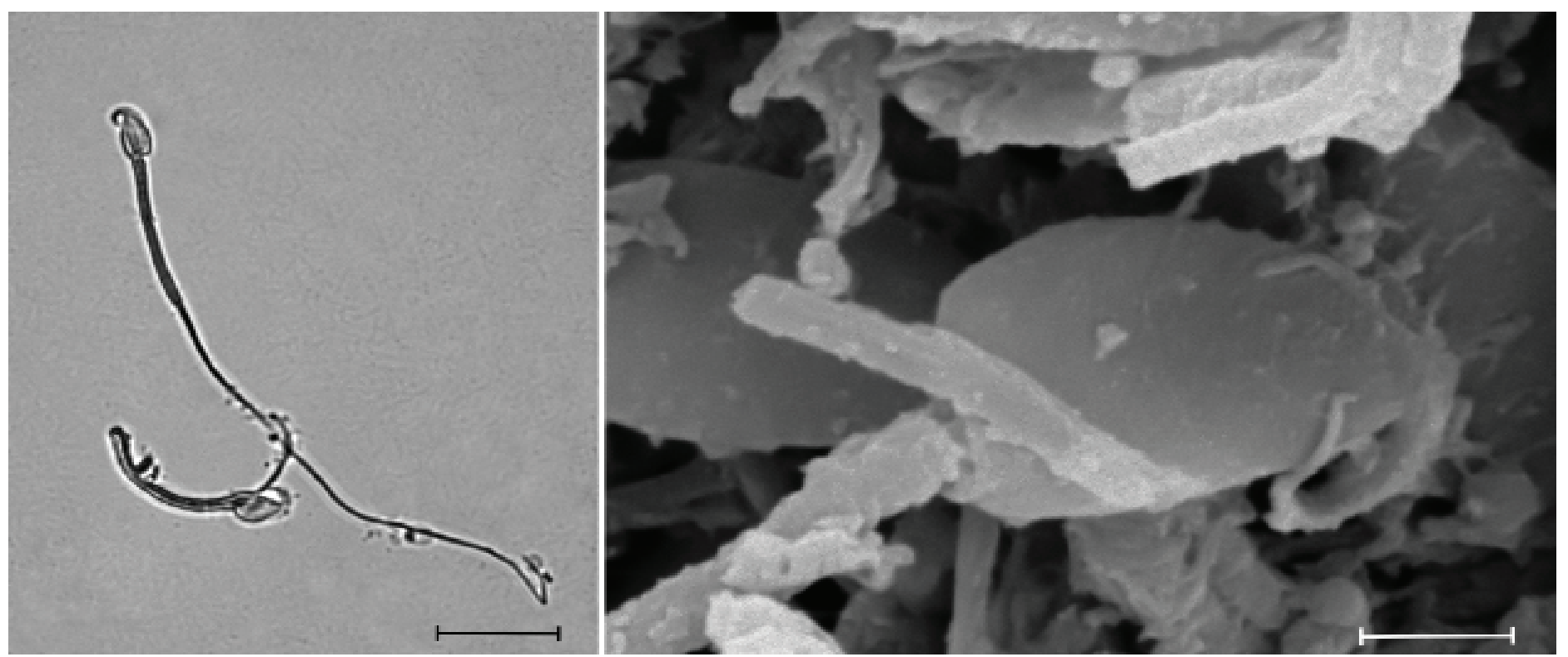

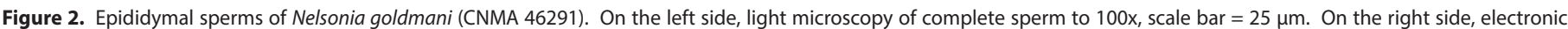
microscopy of the head sperm to $19,000 x$.

\section{Discussion}

The phallus was described in several cricetid species of genus Peromyscus (Hooper 1958) and Neotoma (Hooper 1960). These works identified strong differences between species in the features of the phallus and baculum with relevant implications that show some resemblances with morphological (Carleton 1980) and molecular taxonomic conclusions (Reeder et al. 2006; Miller and Engstrom 2008). Hooper (1959) analyzed the phallus of N. neotomodon and found several characteristics similar to genus Neotoma and other species of closely phylogenetic related genus. Similarly, in this study we found important differences between the phallic features of $N$. neotomodon and $N$. goldmani.

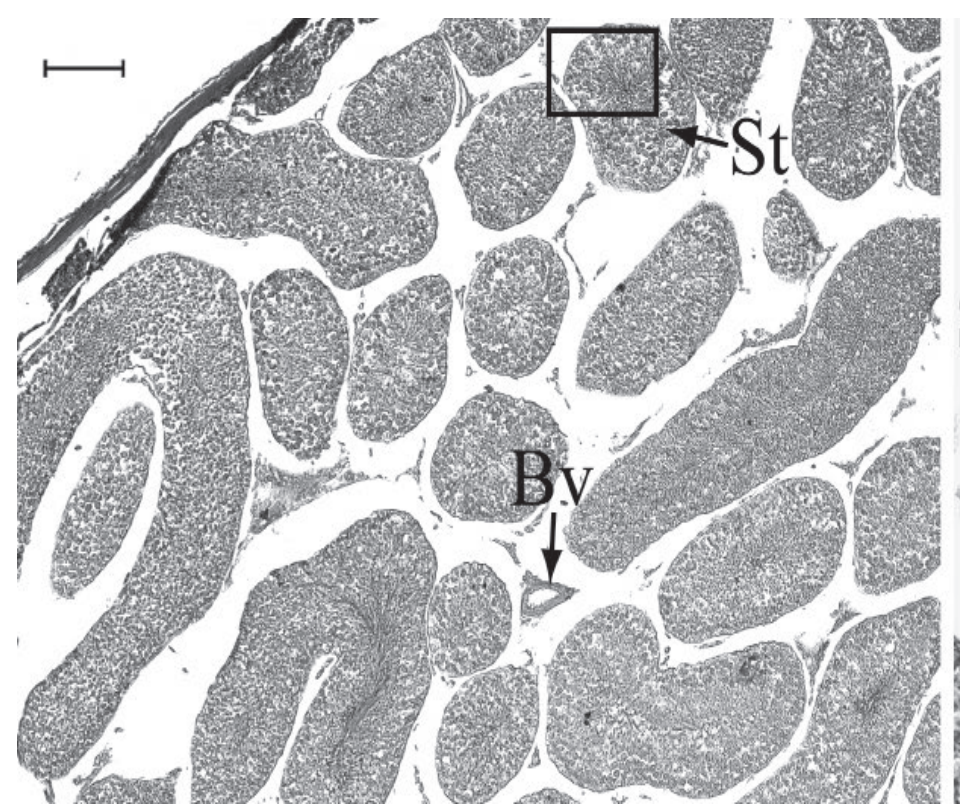

Figure 3. Histology of the testes in Nelsonia goldmani (CNMA 46291). On the left, 10x amplification of cross section of the whole gonad showing seminiferous tubules (St) and

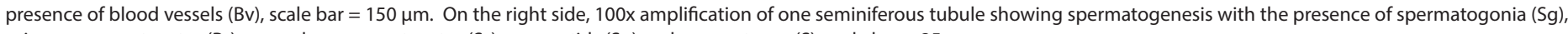
primary spermatocytes (Ps), secondary spermatocytes (Ss), spermatids (Sp) and spermatozoa (S), scale bar $=25 \mu \mathrm{m}$.
In N. goldmani, the total length and diameter of phallus were slightly greater than in N. neotomodon in a proportion of 6 to 5 (Table 1). In addition, the basic shape of phallus was different; the distal section was narrower in $N$. goldmani resembling to a bottleneck and in N. neotomodon as finger-like. The surface with spines present differences between both species, dorsally in N. goldmani the distal spines ended in a convex shape at the middle, which is stronger in N. neotomodon. Ventrally, in N. neotomodon the surface with spines has a concave form, decreasing to middle of proximal section at just above of the base, while in N. goldmani is absent. The surface with pines at the distal end of the phallus was greater in N. netotomodon with a small extension of the middle area, while in N. goldmani was small and without extension.

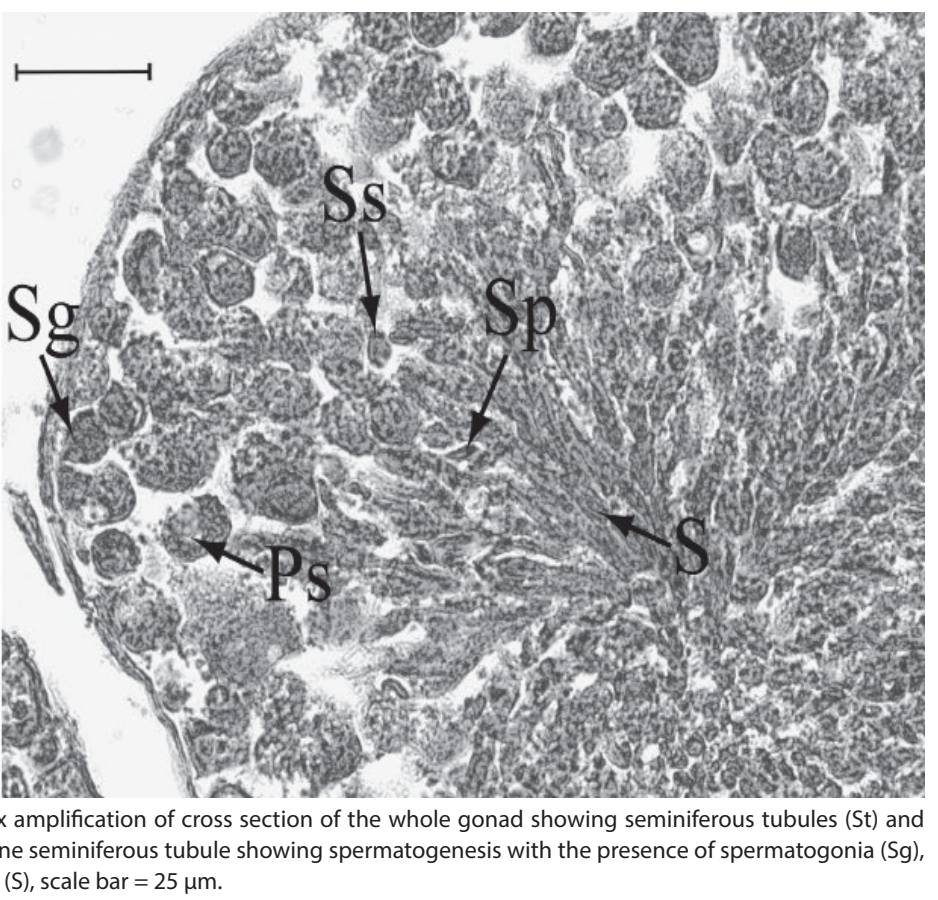


Baculum of both species were different in shape and location, in N. goldmani the proximal section was rounded and begins at the same distance from the gland base and it extends to $1.76 \mathrm{~mm}$ before the terminal distal section of the gland. On the other hand, in N. neotomodon the proximal section of baculum was below the gland base and extends to the terminal distal section of the gland. The proportions of the osseous and cartilaginous sections of the baculum were different in both species. Although it is known that the shape and size of the baculum strongly depends on specimen age (Hooper 1959; Lidicker 1968; Bezerra 2005), the individual of $N$. neotomodon examined by Hooper (1959) and N. goldmani in this study were adults. However, we recognize that any conclusion based on morphology from only one specimen is preliminary, principally because of lack of knowledge about the intraspecific variability.

On the other hand, the basic shape of $N$. goldmani sperm resembles that of other cricetid rodents of genus Peromyscus (Linzey and Layne 1974) and bears greater similarity to Neotomodon alstoni (Villalpando et al. 2000). The size of the sperm was almost the half $(89.6 \mu \mathrm{m})$ that of $N$. goldmani. The sperm size in N. goldmani was greater than other rodents, even those of larger corporal size like some species closely related phylogenetically as Neotoma genus, although the shape evidently differs of these. For example, in Neotoma fuscipes the total length is $125 \mu \mathrm{m}$ with a sharp head and abruptly curved (Wood 1935).

Numerous studies in mammals have shown that competition among spermatozoa of rival males leads to an increase of testicular volume related to the body mass, and the greater size of spermatozoa in order to increase the number and velocity of sperm for more successful fertilization (Harcourt 1981; Roldan et al. 1992; Gomendio et al. 1998; Gomendio et al. 2007; Goméz-Montoto et al. 2011). The spermatozoa of $N$. goldmani are relatively larger to those of other rodents of the same family, with a remarkable hook at the head. These features are correlated directly with a greater sperm swimming efficiency and speed (Roldan et al. 1992; Goméz-Montoto et al. 2011) and is one of the key factors in successful fertilization in sperm competition or no sperm competition situations (Malo et al. 2005; Gomendio et al. 2011; Tourmente et al. 2011).

Histological analysis shows that the adult specimen exhibited active spermatogenesis at the time of its capture on October 2010. Other sympatric rodent species in the same habitat as Neotoma mexicana, and Neotomodon alstoni have different breeding seasons. Neotoma mexicana reproduces in their northern range from March to May (Brown, 1969), for N. alstoni the breeding season is from May to November (Williams et al. 1985). Collections of N. goldmani indicate that one adult male with scrotal testes from Estado de México was captured in late August (Engstrom et al. 1992), while a female found at Jalisco in mid-December had prominent nipples and signs of breastfeeding (LeónTapia and Cervantes 2018). This species is uncommon and difficult to collect to perform histological comparisons at different months in order to determine if spermatogenesis is constant over the year. Whereas the information in this study is preliminary and more specimens are needed to verify the hypothesis, it highlights the need for collecting more specimens of this species and obtaining as much data as possible from each individual.

\section{Acknowledgments}

We would like to thank Posgrado en Ciencias Biológicas of Universidad Nacional Autónoma de México (UNAM). We thank the Instituto de Biología and Facultad de Ciencias of UNAM staff for their support in the production of figures in this study. We give special thanks to M. B. Mendoza Garfias, head of the electron microscopy lab, to A. Luna Sánchez for producing the illustrations, to S. Guzmán Gómez for taking pictures, to M. Villagrán Santa Cruz and E. Mendoza Cruz for helping us to process samples and for observation of the histological analyses. This manuscript was enriched by the comments of two anonymous reviewers.

\section{Literature cited}

Adebayo, A. O., A. K. Akinloye, S. A. Olurode, E. O. Anise, and B. O. Oke. 2011. The structure of the penis with the associated baculum in the male greater cane rat (Thryonomys swinderianus). Folia Morphologica 70:197-203.

Afzelius, B. A. 1982. Sperm structure in relation to function and phylogeny. Pp. 385-394 in The Sperm Cell: Fertilizing Power, Surface Properties, Motility, Nucleus and Acrosome, Evolutionary Aspects (André J., ed.). Proceedings of the Fourth International Symposium on Spermatology, Seillac, France.

Bezerra, A. M. R. 2005. Phallic morphology of Kunsia tomentosus (Rodentia: Sigmodontinae). Mastozoología Neotropical 12:227-232.

Bradley, K. D., D. J. SChmidly, ANd R. D. OWEn. 1989. Variation in the glans penis and bacula among Latin American populations of the Peromyscus boylii species complex. Journal of Mammalogy 70:712-725.

BREED, W. G. 1983. Variation in sperm morphology in the Australian rodent genus, Pseudomys (Muridae). Cell and Tissue Research 229:611-625.

BRowN, L. N. 1969. Reproductive characteristics of the Mexican woodrat at the northern limit of its range in Colorado. Journal of Mammalogy 3:536-541.

Carleton, M. D. 1980. Phylogenetic relationships in neotomineperomyscine rodents (Muroidea) and a reappraisal of the dichotomy within New World Cricetinae. Occasional Papers of the Museum of Zoology, University of Michigan Press 157:11-46.

Cortés-Calva, P., and S. T. Álvarez-Castañeda. 1999. Tamaño gonadal de machos de Chaetodipus arenarius (Rodentia: Heteromyidae) durante un ciclo reproductivo en Baja California Sur, México. Revista de Biología Tropical 47:617-622.

Engstrom, M. D., O. SÁnchez-Herrera, and G. Urbano-Vidales. 1992. Distribution, geographic variation, and systematic relationships within Nelsonia (Rodentia: Sigmodontinae). Prooceedings of the Biological Society of Washington 105:867-881. 
Faulkes, C. G., D. H. Abbott, and J. U. M. Jarvis. 1991. Social suppression of reproduction in male naked mole-rats, Heterocehalus glaber. Journal of Reproduction and Fertility 91:593-604.

FormAN, G. L. 1968. Comparative grass morphology of spermatozoa of two families of North American bats. University of Kansas Science Bulletin 47:901-928.

García-Mendoza, D. F., and C. López-GonzÁlez. 2005. The diminutive woodrat (Nelsonia neotomodon) in Chihuahua, México. The Southwestern Naturalist 50:503-506.

Gomendio, M., A. H. Harcourt, and E. R. S. Roldan. 1998. Sperm competition in mammals. Pp. 667-755 in Sperm Competition and Sexual Selection (Birkhead, T. R., and A. P. Møller, eds.). Academic Press. San Diego, U. S. A.

Gomendio, M., A. F. Malo, J. Garde, And E. R. S. Roldan. 2007. Sperm traits and male fertility in natural populations. Reproduction 134:19-29.

Gomendio, M., M. Tourmente, and E. R. S. Roldan. 2011. Why mammalian lineages respond differently to sexual selection: metabolic rate constrains the evolution of sperm size. Proceedings of the Royal Society of London 278:3135-3141.

Gómez-Montoto, L., M. Varea-Sánchez, M. Tourmente, J. MartínCoello, J. J. Luque-Larena, M. Gomendio, and E. R. S. Roldan. 2011. Sperm competition differentially affects swimming velocity and size of spermatozoa from closely related muroid rodents: head first. Reproduction 142:819-830.

Harcourt, A. H., P. H. Harvey, S. G. Larson, and R. V. Short. 1981. Testis weight, bodyweight and breeding system in primates. Nature 293:55-57.

HOOPER, E. T. 1954. A synopsis of the cricetine rodent genus Nelsonia. Occasional Papers of the Museum of Zoology, University of Michigan 558:1-12.

HoOper, E. T. 1958. The male phallus in mice of the genus Peromyscus. Miscellaneous Publications, Museum of Zoology, University of Michigan 105:1-40.

Hooper, E. T. 1959. The glans penis in five genera of cricetid rodents. Occasional Papers of the Museum of Zoology, University of Michigan 613:1-11.

Hooper, E. T. 1960. The glans penis in Neotoma (Rodentia) and allied genera. Occasional Papers of the Museum of Zoology, University of Michigan 618:1-20.

Hooper E. T., and G. G. Musser. 1964. The glans penis in Neotropical Cricetines (family Muridae) with comments on classification of muroid rodents. Miscellaneous Publications of the Museum of Zoology, University of Michigan 123:1-57.

León-Tapia, M. A., and F. A. Cervantes. 2018. Noteworthy records and ecological niche modeling of the rare and endangered Goldman's diminutive woodrat Nelsonia goldmani (Rodentia: Cricetidae) endemic to central Mexican highlands. Mammalia. DOI: https://doi.org/10.1515/mammalia-2018-0023.

LIDICKER, W. Z. 1968. A phylogeny of New Guinea rodent genera based on phallic morphology. Journal of Mammalogy 49:609-643.

LinZEY, A.V., AND J. N. LAYNE. 1974. Comparative morphology of spermatozoa of the rodent genus Peromyscus (Muridae). American Museum Novitates 2532:1-20.

Malo, A. F., J. J. Garde, A. J. Soler, A. J. García, M. Gomendio, E. R. S. RoLDAN. 2005. Male fertility in natural populations of red deer is determined by sperm velocity and the proportion of normal spermatozoa. Biology of Reproduction 72:822-829.

MerRIAm, C. H. 1897. Nelsonia neotomodon, a new genus and species of murine rodent from Mexico. Proceedings of the Biological Society of Washington 11:277-279.

MerRIAM, C. H. 1903. Four new mammals, including a new genus (Teonopus), from Mexico. Proceedings of the Biological Society of Washington 16:79-82.

Miller, J. R., And M. D. Engstrom. 2008. The relationships of major lineages within peromyscine rodents: a molecular phylogenetic hypothesis and systematic reappraisal. Journal of Mammalogy 89:1279-1295.

Moreira, J. R., J. R. Clarke, and D. W. MacDonald. 1997. The testis of capibaras (Hydrochoerus hydrochaeris). Journal of Mammalogy 78:1096-1100.

Reeder, S. A., S. C. Darin, C. W. Edwards, C. W. Kilpatrick, and R. D. BRADLEY. 2006. Neotomine-Peromyscine rodent systematics based on combined analyses of nuclear and mitochondrial DNA sequences. Molecular Phylogenetics and Evolution 40:251-258.

Roldan, E. R. S., M. Gomendio, and A. D. Vitullo. 1992. The evolution of Eutherian spermatozoa and underlying selective forces: female selection and sperm competition. Cambridge Philosophical Society 67:551-593.

Sikes, R.S., and The Animal Care and Use Committee of the American Society of Mammalogists. 2016. Guidelines of the American Society of Mammalogists for the use of wild animals in research and education. Journal of Mammalogy 97:663-688.

Simson, S., L. Ferrucci, C. Kurtonur, B. Ozkan, and M. G. Filippucci. 1995. Phalli and bacula of European Dormice: description and comparison. Hystrix 6:231-244.

Tourmente, M., M. Gomendio, and E. R. S. Roldan. 2011. Sperm competition and the evolution of sperm design in mammals. BMC Evolutionary Biology 11:12.

Villalpando, I., H. Villafan-Monroy, D. Aguayo, A. Zepeda-Rodriguez, E. Humberto-Granados, and A. Chavez-Olivares. 2000. Ultrastructure and motility of the caudal epididymis spermatozoa from the volcano mouse (Neotomodon alstoni alstoni Merriam, 1898). Journal of Experimental Zoology 287:316-326.

Williams, S. L., J. Ramírez-Pulido, and R. J. Baker. 1985. Peromyscus alstoni. Mammalian Species 242:1-4.

Wood, F. D. 1935. Notes on the breeding behavior and fertility of Neotoma fuscipes macrotis in captivity. Journal of Mammalogy 16:105-109.

Associated editor: Monica Díaz

Submitted: January 8, 2019; Reviewed: Febreary 25, 2019;

Accepted:March 8, 2019; Published on line:April 7, 2019. 